\title{
Kommunismens eftermæle
}

\section{Museer og erindringspolitik i Østeuropa}

\author{
LeNE OTTO*
}

Title: The legacy of Communism. Museums and Politics of Memory in Eastern Europe.

Abstract: In the post socialist countries the memory of communism is in the making. How to remember the period between WW2 and the fall of the Soviet Union is a disputed and contested subject in dissertations, in the activities of the so called institutes of national commemoration, founded in several post socialist states, in movies, in conferences, in commemorations and not least in museums. This article investigate how he heritage of communism is handled, collected and exhibited in some museums founded after 1989 in Hungary, Lithuania, Romania and Germany. The museums analysed are the "House of Terror" in Budapest, "The Museum of Genocide Victims" in Vilnius, "The Memorial of the Victims of Communism and of the Resistance" in Sighet (Romania) and "The DDR museum" in Berlin. These museums of communism are analysed in the framework of politics of memory and culture of memory. My approach is infuenced by the New Museology putting techniques of representation in focus. By examining the staging of communism in museums I will not only find out what pictures of communism are produced, but also what effects politically and as regards identity these representations have. It is not my purpose to find out if the museum representations are true or in agreement with historical facts, but rather how the staging of communism in museums interacts with, constitute and change reality.

Key words: memory, communism, post socialist politics of memory, museums, memorial, terror, victims, "House of Terror", "The Museum of Genocide Victims" "The DDR museum".

I efteråret 2004 afholdtes et symposium i Weimar om museernes erindringspolitiske rolle $\mathrm{i}$ forbindelse med formidlingen af den kommunistiske fortid. ${ }^{1}$ Museumsfolk fra Tyskland og det tidligere Østeuropa diskuterede brugen af fortiden i nutiden ud fra den antagelse, at museerne er erindringspolitisk vigtige steder. Te- maerne var historiekultur, udstillingskoncepter og immanente identitetspolitiske hensigter i de nye museer og udstillinger om tidsperioden 1945-1989 med særligt henblik på kommunismen. Både indlæg og diskussioner er senere udgivet som bog. ${ }^{2}$

Kommunismens eftermæle kom tidligere på 
den erindringspolitiske dagorden i Tyskland end i de øvrige europæiske lande fordi den postsocialistiske erindring i DDR skulle indarbejdes $\mathrm{i}$ en ny national fortælling om det genforenede Tyskland. Den første store museumsudstilling som bidrog til dette, var udstillingen Lebensstationen i begyndelsen af 1990'erne på det historiske museum Zeughaus i Berlin. Her forsøgte museet at sammenføje to fortællinger om dagliglivet i Østtyskland og Vesttyskland efter 1945. Ifølge tysk tradition forholdt udstillingen sig samtidig reflekteret til spørgsmålet, om museerne først og fremmest er erindringspolitiske aktører eller erindringspolitiske instrumenter, og i så fald for hvem eller hvad?

Dette spørgsmål var også den røde tråd i diskussionen på symposiet $\mathrm{i}$ Weimar ti år senere. De tilstedeværende museumsfolk mente, at museerne, ikke mindst i det tidligere Østeuropa, har stor symbolsk magt; det vil sige, at museernes har store muligheder for at præge den politiske dagsorden i deres hjemlande. Jo yngre en begivenhed er, jo mere umiddelbart politisk anvendelig synes den at være. Således har museerne vist sig at være vigtige redskaber i opbygningen af de nye post-socialistiske stater; både som dannelsesinstitutioner for befolkningen og som formidlere af landets rette forståelse af fortiden, som skal give de nye stater anerkendelse i resten af verden.

Efter at jeg gennem flere år har besøgt mange af disse museer og mindesmærker mener jeg, at kunne se en tendens til, at museerne tager denne rolle alvorligt og at de har mange politiske og sociale dagsordner. De vil både dokumentere kommunismens magtformer, de-legitimere kommunismen og bidrage til at (re)konstruere en national identitet. Således må museerne ses som ikke uvæsentlige aktører i den postsocialistiske bearbejdning af kom- munismen, som efter 1989 er blevet genstand for en voldsom, global erindringspolitisk diskussion. Diskussionen næres af det politiske og eksistentielle spørgsmål, hvordan de 50 år med kommunistisk styre i Østeuropa skal erindres? Svaret er ikke entydigt, og ordene har stor magt, det er ikke ligegyldigt om man vælger ord som diktatur og terror eller mere lægger vægt på den sociale tryghed og sammenholdet i de kommunistiske stater.

I alle de postsocialistiske lande pågår der en bearbejdelse af erindringen om kommunismen og derved produceres der efterhånden en kollektiv erindring. Den kollektive erindring skabes som et konglomerat af akademiske afhandlinger, rapporter fra såkaldte erindringsinstitutter, som der er oprettet i flere postsocialistiske lande, af dokumentar og spillefilm, af organiserede debatter og offentlige mindearrangementer samt ikke mindst $\mathrm{i}$ form af $\mathrm{mu}$ seumsudstillinger.

Denne artikel undersøger, hvordan den kommunistiske kulturarv indsamles, bearbejdes og formidles på fire museer, der er oprettet efter 1989 i Ungarn, Litauen, Rumænien og Tyskland. Det drejer sig om museerne "House of Terror" i Budapest, "The Museum of Genocide Victims" i Vilnius, "The Memorial of the Victims of Communism and of the Resistance" i Sighet, Rumænien og "The DDR museum" i Berlin. ${ }^{3}$ For de tre første museers vedkommende gælder, at de ud over at være museum også er et mindesmærke, forstået på den måde at de er bygninger, hvori de historiske begivenheder, de skal erindre om, faktisk foregik. De er mindesmærkemuseer eller memorial museums. ${ }^{4}$

De fire udvalgte museer om kommunismen ses i det følgende i en bredere erindringskulturel og erindringspolitisk sammenhæng. Min tilgang er præget af den nye museologi, som 
sætter repræsentationsteknikkerne i fokus. Ved at undersøge iscenesættelserne af kommunismen på museerne, vil jeg ikke bare undersøge, hvilken forestilling om kommunismen der produceres, men også hvilke politiske og identitetsmæssige effekter disse repræsentationer har. Det er altså ikke hensigten at undersøge, om museernes repræsentationer stemmer overens med virkeligheden, men snarere hvordan museale repræsentationer af kommunismen kan gribe ind i, konstituere og forandre virkeligheden.

\section{KONFRONTATION, EMOTIONALITET OG KOL- LEKTIV IDENTITET}

Museer er samfundsmæssige institutioner, der forvalter fortiden i fællesskabets navn og som organiserer og formidler den kollektive erindring. Måske er det en mysticisme at tale om, at samfund har en erindring eller en hukommelse, men i alle samfund produceres og materialiseres erindring $\mathrm{i}$ form af riter, monumenter, museer og mindesmærker. I den forstand er erindring en kollektiv, refleksiv, betydningsskabende praksis med mange aktører, men museerne, ikke mindst når de er placeret i hovedstæder, må betragtes som flagskibe i et lands erindringskultur. Dette er fælles for museerne i øst og vest, men i denne artikel vil jeg vise, at museernes historieforvaltning $\mathrm{i}$ de postsocialistiske lande i mere udpræget grad også tjener et terapeutisk formål. Udstillingerne om kommunismen tjener også mere følelsesmæssige formål som forsoning, heling og frigørelse. Det terapeutiske og det kritiske refleksive ses ikke som uforenelige strategier. ${ }^{5}$

I den proces er det en udbredt overbevisning, at sandheden om fortiden virker helbredende på sjælen - den individuelle såvel som den kollektive. I denne forståelse ligger det som en forudsætning, at konfrontationen med sandproces, før man kan kigge fremad. Konfrontationen fremtvinges blandt andet med brugen af individuelle erindringer som sandhedsvidner ofte formidlet med portrætter og navne. De bruges til tvinge publikum til at konfrontere sig selv med fortiden, til at betragte bødlernes og ofrenes ansigter og til kropsligt komme i nærkontakt med de frygtede steder. Denne kropslige kontakt, fx når den besøgende står i et tidligere torturkammer og konfronterer rædslerne er nærmest excorcistisk: det onde skal uddrives, for at den kollektive identitet kan heles. Med Giorgio Agambens ord kan man sige, at museerne forsøger at forene to erindringsstrategier, nemlig at være både vidneskranke og arkiv (Agamben 1999), dvs. at være steder for både sandhed og heling.

Museerne i de postsocialistiske lande forsøger at være rum for både terapeutisk konfrontation og sandhed. Udstillingssproget forekommer derfor langt mere emotionelt og samtidig mere kontant end det er almindeligt på traditionelle vestlige museer. ${ }^{6}$ Samtidig ses en udbredt tendens at tale direkte om tingene og at undgå eufemismer; folkemord er $\mathrm{fx}$ en udbredt betegnelse for de politiske forfølgelser, ligesom de nævnte navne og portrætter af afdøde borgere indgår som fast element i de fleste udstillinger. Fælles for de museer, der vil blive analyseret i det følgende er således, at de både er kulturhistoriske museer og sakrale steder for meditation, bøn, tårer og udlevelse af stærke følelser i det hele taget. Det gælder fx House of terror museet i Budapest, hvor lederen udtaler:

I like the Room of Tears the best, because one can meditate there for a while and think about those who became victims of the dictatorships. And you can also 
bow to the memory of the heroes; those who chose resistance knowing that they were risking their lives or their freedom, but they still confronted the dictatorship. It is a good thing that there are such examples, and that in the end they gained victory. (Schmidt 2005).

Museet arrangerer også hvert år en mindehøjtidelighed den 25 . februar, som er udnævnt til The Memorial Day of the Victims of Communism. På denne dag er der gratis adgang til museet og folk opfordres til at komme og tænde et lys for ofrene. Det at supplere udstillinger med ritualiserede mindefester er i det hele taget udbredt på de postsocialistiske museer. Denne sammenblanding af det historiske og det spirituelle er umiddelbart det, der adskiller de postsocialistiske museer mest markant fra traditionelle kulturhistoriske museer.

\section{FORSKELLIGE ERINDRINGSKULTURER}

Selvom man kan pege på sådanne tendenser, der er fælles for de postsocialistiske lande, er disse lande i sagens natur også forskellige. Kommunismen er et følsomt emne, som er stærkt omgærdet af emotionelle holdninger. Formidlingen af den på museerne er både præget af de personer, der er aktive, af den nationale erindringskultur, de er en del af og af globale erindringsdiskurser. Derfor kan man med en vis ret tale om, at der eksisterer forskellige nationale erindringskulturer, som museerne er en del af. Inspireret af Troebst (2005: 36-41) skelner jeg i det følgende mellem erindringskulturer, der er præget af:

\section{- konsensus}

Kommunismen afvises kategorisk om væsensfremmed (eller etnisk fremmed). Det gælder i udpræget grad de baltiske lande, i det følgende eksemplificeret af "The Museum of Genocide
Victims" i Vilnius. I centrum står den nationale modstand mod besættelsesmagterne i form af partisanbevægelserne. Udstillingens ledemotiv er offer og modstand.

- kontrovers eller konflikt

Erindringskulturen er præget af heftig politisk diskussion og erindringskontroverser mellem forskellige grupper, som det foregår i Ungarn, Polen og Tjekkiet, i det følgende eksemplificeret ved "House of Terror" i Budapest.

\section{- ambivalens og apati}

Kommunismen anses som en fremmed magt, men dens evne til at skabe modernisering gør, at den ikke kun skal erindres om dårlig. Erindringen er mindre spektakulær og mindre omdebatteret i lande som Rumænien, Makedonien og Serbien-Montenegro, i det følgende eksemplificeret ved "Memorial Sighet" i et udkantsområde i Rumænien.

Artiklen rundes af med en diskussion af et museum, der repræsenterer en helt anden tilgang til den kommunistiske fortid. Det drejer sig om "The DDR Museum. A hands-on experince of everyday life" i Berlin, som ikke anlægger en konfronterende, sandhedssøgende strategi. I stedet er museet selvbevidst nostalgisk eller ironisk-nostalgisk. Den selvbevidste eller refleksive nostalgi forsøger at konstruere en fortid, som ikke er præget af vestens tolkninger, men er ens egen. Udstillingen er ikke sentimental, dvs. uden distance og den udtrykker heller ikke direkte en længsel efter det tidligere politiske system, men forsøger på at skabe forbindelse mellem befolkningen og historien på en måde, hvor udstillingsplanlæggerne selv er klar over, at de anlægger et nostalgisk perspektiv på historien. Denne erindringspolitiske strategi er blevet kaldt OSTalgi, og den har hidtil været mere anvendt i film, som fx "Goodbye Lenin!" end som museumskoncept. 
MuseUM OG MINDESMÆRKE

De første tre museer, som vil blive diskuteret i det følgende er som nævnt både museum og memorial i den forstand, at bygningen udover at huse et museum samtidig er et mindesmærke over forbrydelser, der blev begået i bygningen under kommunismen, men deres erindringskulturelle udtryk er meget forskellige.

I Budapest blev der i 2002 åbnet et museum tilegnet ofrene for nazismen og det kommunistiske styre. Adressen er ikke tilfældig. Fra 1937 fungerede det store palæ under navnet
"House of Loyality" som hovedkvarter for det De ungarske nazister brugte kælderen som fængsel fra de kom til magten i 1944. Det hemmelige sikkerhedspoliti brugte huset fra 1945 til 1956, hvorefter det blev brugt som domicil for forskellige firmaer, mens den tidligere fange- og torturkælder blev brugt som tilholdssted for ungkommunister. På få år er det blevet "a place of pilgrimage". Mere end $1 \mathrm{mil}$ mennesker har set udstillingerne.

I Litauens hovedstad Vilnius blev der allerede i 1992 etableret museum i det tidligere KGBhovedkvarter. Det blev reetableret i 1997 som

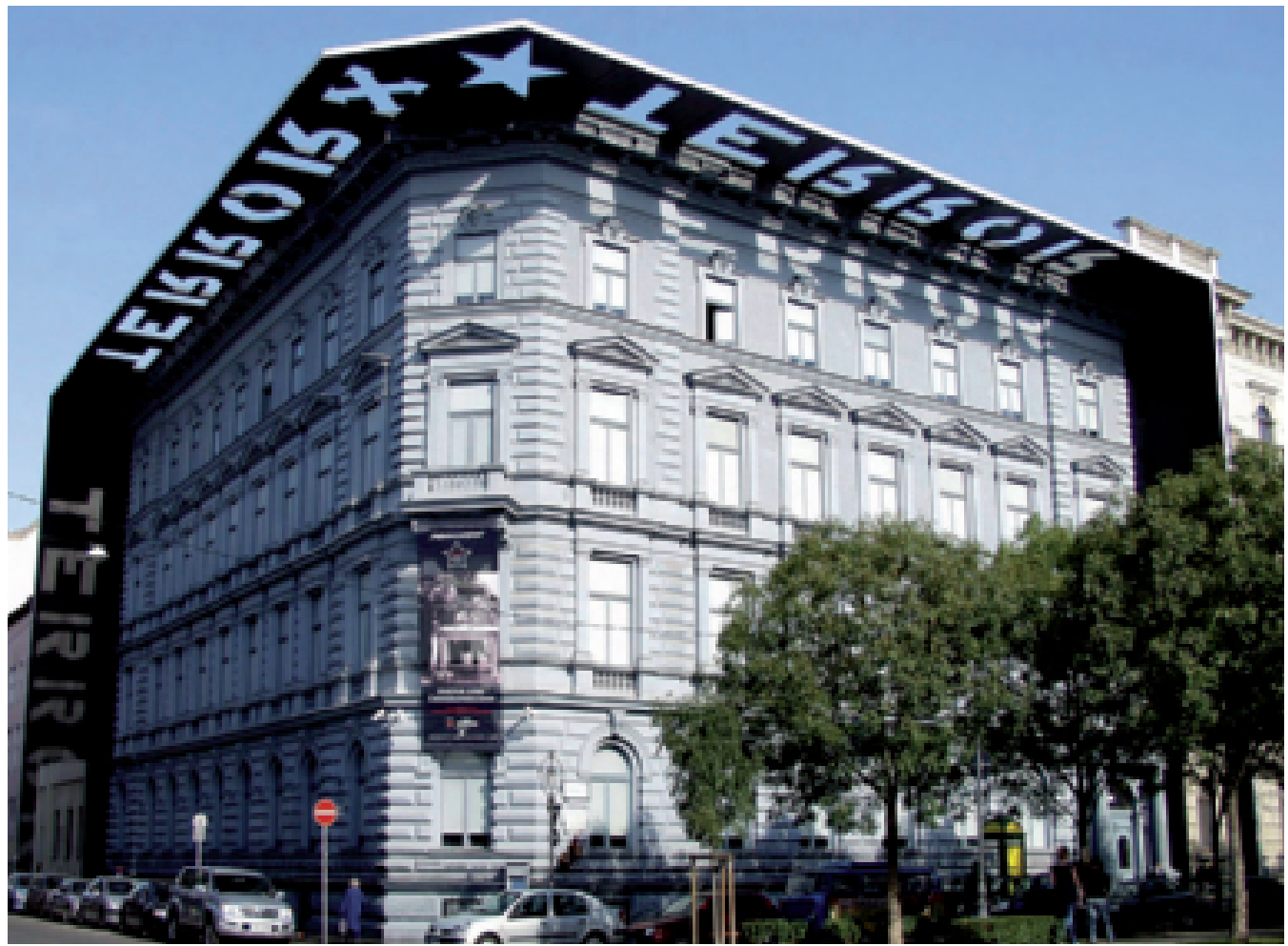


10 The Museum of Genocide Victims under ledelse af "The Genocide and Resistance Research Centre of Lithuania". ${ }^{7}$ I museet er kommunismens folkedrab ledetråd for udstillingen.

The Memorial Sighet åbnede 1997 i det forhenværende "Prison of the Ministers" $i$ byen Sighetu Marmatiei ("Sighet”) som ligger i Maramures regionen i det nordvestlige Rumænien, kun $2 \mathrm{~km}$ fra den ukrainske grænse. Museet eller mindesmærket, som er etableret med midler fra Europarådet, er en del af et større et internationalt center for studier i kommunismen.

De tre museer repræsenterer forskellige måder at erindre kommunismen på. I Budapest lægges der vægt på at fremstille og dokumentere regimet og dets terrorisering af befolkningen, i Vilnius fokuseres på ofrene $\mathrm{i}$ både fysisk og spirituel forstand, som et folkemord og i Rumænien er emnet kommunismen som ideologi og styreform, men også de rumænske ofre, der blev sat i fængsel for deres kritik af systemet. Forskellighederne til trods repræsenterer disse tre museer en bredere museal tendens, der har været tydelig fra 1980'erne, hvor stadig flere museer etableres, der bevidst ekspliciterer den moralske dimension ved fremstillingen af tragiske, historiske begivenheder. Hertil hører ofte en strategi, hvor museumsbesøget skal fremme en ønskelig social respons som at få de besøgende til at sørge, at tilgive og i det hele taget befordre en moralsk stillingtagen. Tendens hænger samme med, at mange af de begivenheder, som står centralt i moderne erindringspraksis, berører ikke blot specifikke nationer, men også menneskeheden som sådan, fx holocaust, Hiroshima, kolonisering, slavehandel, terrorisme og folkemord (Williams 2007).

Selvom det er en grov forenkling, kan man med en vis ret sige, at kontrasten til det sandhedssøgende og moralsk engagerende museum er det mere selvrefleksive, postmoderne og ironiske museum, der 'leger' med historien. Museer af den type findes som nævnt også blandt den brogede skare af museer, der forvalter kommunismens kulturarv. Hvordan de forskellige museer konkret og udstillingsmæssigt forvalter historien om kommunismen, vil blive analyseret i det følgende.

\section{"TERRORHÁZA"}

Museet Terrorháza i Budapest er bygget op som en historie om Ungarns besættelse og underlægning under to diktatoriske styrer, de 5 år med nazistisk styre fra det ungarske nazistpart blev stemt til magten i 1939 (tysk besættelse marts 44-august 44) og den efterfølgende sovjetiske besættelse fra august 44 til juni 91, hvor den sidste sovjetiske soldat forlod landet. Denne soldat nævnes endda ved navn.

Tonen slås an allerede når man står ude på gaden foran bygningen. Der er monteret en metalplade på taget med de udstansede bogstaver TERROR, som når solen skinner igennem dem, spejler ordet på facaden og på fortovet. Inden for indgangsdøren er en stor pompøs marmortrappe op til udstillingen, opdelt i midten af et gelænder og for enden af trappen hænger et rødt banner med en hvid stjerne og et sort banner med et hvidt pilekors (de ungarske nazisters symbol svarende til det tyske hagekors). Budskabet er, at der ingen forskel er mellem det nazistiske parti Arrow Cross og det kommunistiske parti, der kom til magten efter krigen og derfor heller ikke mellem kommunisme og nazisme på et mere generelt niveau. Udstillingen forløber over tre etager omkring en overdækket atriumgård, 
hvor der er placeret en sovjetisk tank. På væggene omkring den er der fra gulv til tag opsat hundredvis af små sort-hvide portrætfotos. Eneste tekst er ordet Victims.

Udstillingen starter på anden sal. Det første rum viderefører temaet om den dobbelte besættelse af fremmede magter. Det onde kommer udefra, forstår man, selvom det ikke egentlig forties, at Ungarn selv havde et nazistisk såvel som et kommunistisk parti, som begge havde bred opbakning i befolkningen. Fremstillingen fritager ikke ungarerne fuldstændig for ansvaret for egen skæbne, men det samlede indtryk er, at den ungarske nation først og fremmest er offer, først for det Tredje Rige, og siden for Sovjet.

Gennem en sort korridor med navnene på de ungarske nazister kommer man til næste rum, der omhandler det ungarske nazistparti. Det er indrettet som mødesal med bordopdækning med nazisymboler og den ungarske nazistleders ansigt $\mathrm{i}$ fotostat monteret på en fuld uniformeret krop for enden af bordet. Bortset fra figuren, tallerknerne og en skærm med en film af isflager, der driver i vand, er alt sort. Teksten forklarer, at isflagerne flyder på Donau, på hvis bred en gruppe forfulgte jøder blev skudt af nazisterne. Rummet fortæller også om ungarernes deltagelse i den nationalistiske og anti-semitiske bevægelse, samt i jødeforfølgelserne, men det pointeres, at styret var indsat af og støttet af Tyskland. Udstillingen fortsætter $\mathrm{i}$ et kæmpestort, sortmalet rum med et kort over Sovjetunionen i gulvet, hvor alle Gulag-arbejdslejrene er indtegnet. Mange lejre er markeret med omvendte kegler, hvor bunden, der vender op ad, fungerer som en montre med genstande fra ungarske fanger, der havde opholdt sig i lejeren, fx bibler og ure. Alene rundturen omkring kortet giver tilskueren en fysisk fornemmelse af Sovjet, som en på alle måder kæmpemagt. Et følgende 11 rum fortæller, at kontinuiteten i diktaturerne også forgik på det individuelle niveau, i form af vendekåberne. En gine er beklædt med en nazistisk uniform på den ene side og en kommunistisk uniform på den anden side for at vise, hvordan de politisk aktive skiftede side af opportunistiske grunde efter 1945, da den Røde hær havde fordrevet nazisterne fra Ungarn.

Resten af museet er en form for kronologisk gennemgang af Ungarns historie under kommunistisk styre. Kommunistpartiets dominans slås an med store portrætter og draperet rødt stof. Lytteudstyr bruges i udstillingen til at beskrive forandringen af samfundet og af befolkningen. Hverdagen under kommunismen beskrives som tvangssocialisering, frygt og ensretning. Det betones, at der var tale om en tvangssocialisering af den ungarske befolkning med værdier, der var dem totalt fremmed. ${ }^{8}$ Dokumenter og nyhedsklip påkalder fornemmelsen af Sovjetstyrets uafbrudte tilstedeværelse i dagliglivet. Flere rum er kontorinteriører med propagandaplakater, marxistiske bøger, billeder af Stalin og utallige faner med hammer og segl. De illustrerer sovjeteksperternes tilstedeværelse i Ungarn, men man er i tvivl om, hvorvidt det er en tilfældig sammensætning af kommunistisk "kitsch" eller en autentisk indretning. Næste rum er dedikeret til modstandsbevægelsen. Det er et æstetisk rent rum med tre podier med tre borde, stole og lamper, som repræsenterer tre sociale klasser. De symboliserer, at modstand og patriotisme samlede den ungarske nation på tværs af sociale skel. Modstandsbevægelsen er nationens helte, som ikke må glemmes.

Man går ned af trappen til første sal og gennem en smal gang til et åbent rum, hvor deportation og folkeforflytninger tematiseres 
12 helt enkelt med en stor sort bil bag et sort forhæng. Den er både en relikt fra en tid, hvor dens blotte tilstedeværelse varslede, at sikkerhedspolitiet kom for at hente en mistænkt, men den hentyder også til den nye opstigende klasse, partiets såkaldte kadre, som fik let adgang til materielle goder. Det antydes, at den nye herskende klasse fik overdraget de deporteredes og forflyttedes boliger og indbo. I en smal passage ses først et torturkammer, der står i sin originale form med en vandhane på væggen og en rist i gulvet. Teksten er en detaljeret fangeberetning. Efterfølgende møder man en stor papmachégris. Væggene er store klodser af gullig-hvid sæbe. Den tilhørende tekst fortæller om styrets behandling af bønderne, om hvordan de blev tvunget til at aflevere en del af produktionen, om tvangskollektivisering, om statens latterliggørelse af selvejet og om den generelle ødelæggelse af livsformen. Resultatet var et mangelsamfund, symboliseret ved sæben.

De næste to rum handler om sikkerhedspolitiet. Midt i rummet er placeret en rød stjerne på en piedestal og på den ene væg en stor tavle med billeder af og navne på medlemmer af sikkerhedspolitiet. ${ }^{10}$ Derefter kommer man ind $\mathrm{i}$ lederen af sikkerhedspolitiets kontor med et pompøst skrivebord. Den ene halvdel af rummet inklusiv et hjørne af skrivebordet og halvdelen af vinduet er overmalet med en grålig farve, mens resten står i naturlig farve. På den grå halvdel står også en fængselsseng. Teksten forklarer, at selv de mest partitro ledere kunne blive ofre for sikkerhedspolitiets arbejde, som deres egen leder, der faldt i unåde, fordi han var jøde. Han blev fængslet i forbindelse med Stalins anti-semitiske kampagner i begyndelsen af 1950'erne. Det følgende rum er tapetseret med arkivalier - udskrifter fra afhøringer, retssager, og undersøgelser - på gul-

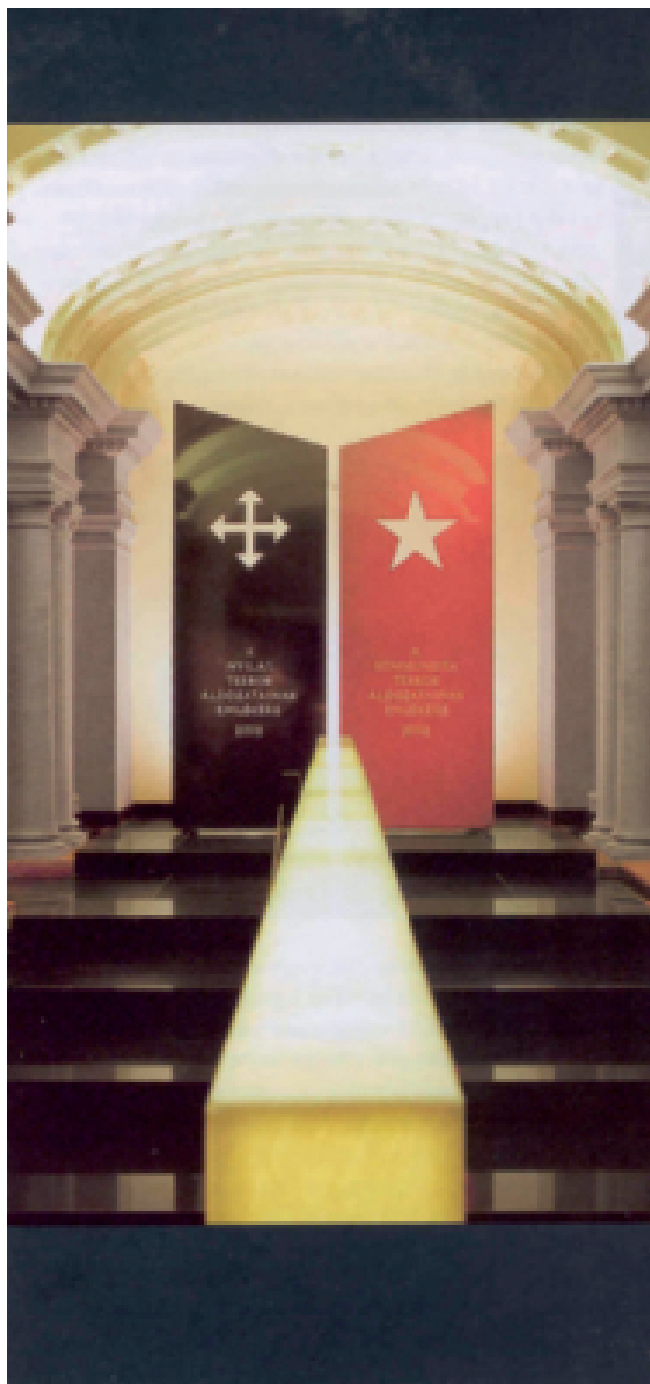

Trappeindgangen til museet Terrorhaza iscenesatter fortallingen om Ungarn som underlagt to på hinanden folgende terrorregimer, nazismen og kommunismen. Budapest 2006. Foto: Lene Otto.

vet og på rækker af borde og bænke. De giver et råt og koldt indtryk. På alle væggene er reo- 
ler med arkivmapper. I det næste rum er væggene derimod tapetseret med farvestrålende propagandaplakater og reklamer for fim og almindelige konsumprodukter. Æstetikken er umiskendelig fra1960'erne, og stemningen virker naiv og forlystelsessyg som tiden. ${ }^{11}$ Der er også en udstilling af lokale hverdagsprodukter i ungarsk sølv, dvs. aluminium. Langt fra at fremme nostalgi skal de grå genstande på grå hylder i et gråt rum vække følelsen af en grå hverdag. På samme måde er det næste rum indrettet, så det vækker følelser. Det er et meget langt rum, som har fået et hvælvet, hvidt loft. Herunder er et langt kors med lys indlagt i gulvet. For enden, som et alter, er ophængt en præstekjole. Indbygget i væggene er flere små montrer med de forskellige trosretningers religiøse genstande. Stemningen er sakral. Her findes også udstillingens længste tekst om de politiske ideologiers destruktion af det religiøse liv. Det sidste rum er et mindesmærke over den katolske kirkes overhoved, kardinal Mindszenty, som blev forfulgt af både nazister og kommunister.

Den eneste udgang fra udstillingen er en elevator. Når den er fyldt op, lukker døren og elevatoren begynder en uendelig langsom nedstigning samtidig med at der på en kæmpeskærm inde $\mathrm{i}$ elevatoren toner en tidligere fangevogter frem, som detaljeret fortæller om den tortur, han har medvirket til at udføre i den kælder, man nu kommer ned i. Man fyldes med en klaustrofobisk og ubehagelig følelse. I kælderen kan man se de rekonstruerede fange-, forhørs- og torturlokaler. Der er også et rum til minde om minearbejderne i straffelejrene og nogle af deres personlige ejendele, som de har lavet i lejrene, såsom briller, lighter, et kors, en cigaretpakke og nyheder skrevet på cigaretpapir. Et andet rum om oprøret i 1956 er udformet som et mindesmærke over

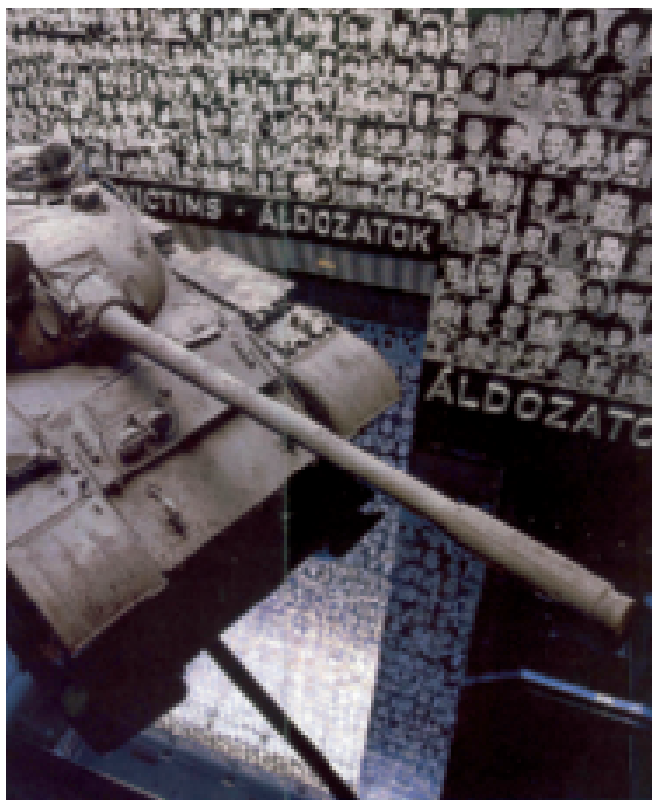

Atriumgard med fotos af ofre for Ungarns to terror regimer. Terrorhaza, Budapest 2006. Foto: Lene Otto.

de faldne helte. En læderfrakke hænger på en bøjle i loftet og minder om en hængt person. Under denne er en montre udformet som en kiste med glasvinduer, så man kan se nogle af oprørernes ting, blandt andet en molotovcocktail og en riffel. Der er en stemning af død og tabte muligheder, som fortsætter i det næste rødmalede rum, hvor der er opstillet fire skafotter med appeller fra de dømte. I modsætning hertil er det næste rum fyldt med postkort fra alverdens eksotiske steder som er sendt hjem til ungarske familiemedlemmer og venner af folk, der flygtede fra Ungarn efter revolutionen. Det virker helt kitschagtigt og står derfor også i stærk kontrast til det den næste "Hall of tears", hvor navnene på alle de, der blev elimineret mellem 1945 og 1967, står skrevet på væggene. Midt i rummet er der 
14 rækker af kors med jødestjerner - både kristne og jøder var ofre.

Tiden fra 1967 til 1989 præsenteres på skærme, der viser optagelser af vigtige begivenheder som fx demonstrationer i 1980'erne, ødelæggelsen af ungarske landsbyer i Rumænien, John Paul II's besøg i Ungarn og de sidste sovjetiske tropper, der forlade landet. På vej ud må man passere "The perpetrators' wall". Her er portrætter af alle, der støttede de to regimer, dvs. var ansatte i de to styres lovgivende, administrative og udøvende organer. Som $\mathrm{i}$ indgangsrummet er teksten kort og fyndig, den lyder: Victimizers. Der er navne og data på alle, hvoraf mange er nulevende.

Museet har i hele sin korte levetid været heftigt debatteret og kritiseret, men også rost og velbesøgt. I den europæiske museumsverden har det fået anerkendelse, idet det blev nomineret til Museum of the Year i 2004. I dommernes rapport om de indstillede museer hedder det:

The House of Terror in Budapest arouses strong feelings in its visitors, as it housed the headquarters of the Hungarian Nazi Arrow Cross Party before the Second World War and later the political secret police of the Communist regime. Each room has its own environment, with theatrical effects mixed with original pieces, the philosophy being closer to a contemporary art installation than a conventional museum display with showcases and text panels. The uncompromising portrayal of recent history has generated strong political debate in Hungary as many people who are still alive have experiences of the House of Terror, both as interrogators and those who were brought to the building for questioning. It was felt by the EMF Committee that the presentations in the museum were founded on sound research and succeed in keeping alive the memory of a series of terrible political and social experiences in Hungary without sensationalising them. (http://www.europeanmuseum forum.org).

I kontrast til denne ros handler en stærk og vedvarende kritik om det legitime $i$ at parallelisere nazismens kortvarige, men effektive udryddelse af 600.000 ungarske jøder med 44 års politisk undertrykkelse af den ungarske befolkning. Er sammenligning overhovedet mulig eller relevant? Det kritiseres, at selvom indgangspartiet giver indtryk af, at de sidestilles, bruges der alligevel kun tre rum på den nazistiske periode, mens resten af huset omhandler overgreb begået under kommunismen. Så uanset den tilstræbte objektivitet ligger svaret måske i den fysiske disponering af fortællingen.

Kritikken imødegås i utallige sammenhænge af museets leder Mária Schmidt, som er en kendt historiker og ideolog tilhørende den intellektuelle højrefløj, som fungerede som rådgiver for statsministeren under Orbán regeringen. Hun har bevidst opbygget museet som et sted, hvor den ungarske nation kan få oprejsning og hun ønsker, at museet fungerer som et pilgrimssted. I et interview i avisen $\mathrm{Di}$ plomata den 20. oktober 2005 fortæller hun, hvad det er for en interesse der driver hende ${ }^{12}$ :

We would like to touch our visitors' hearts. We would like our museum to become a national place of commemoration where we can bow together to the victims of those terrible dictatorships.

Lederen udtrykker desuden, at hun er chokeret over, at venstrefløjens beskyldning om at museet er et politisk redskab, der formidler det budskab, at venstrefløjen repræsenterer samme politik som Stalin. Før valget i april 2005, hvor den højreradikale Viktor Orbán måtte træde tilbage, udtalte socialisterne, at House of Terror skulle omdøbes til House of 
Remembrance and Reconciliation, hvis de vandt. Dette er dog endnu ikke sket.

Det er ikke kun venstrefløjen der er kritisk, det gælder også jødiske organisationer i og uden for Europa. Socialister og liberalister i Ungarn beskylder museet for at være et redskab for højrekræfterne. "That was why it got immense money and was completed in record time" mener Tibor Vamos, der er jøde, tidligere kommunist og nuværende leder af den ungarske Auschwitz Foundation. De ungarske jøder er dybt bekymrede for langtidsvirkningerne af museet måde at fortælle historie på. Når alle ofre og alle bødler gøres lige, som det sker i udstillingen, underspilles det unikke i Holocaust. Kritikken lyder videre, at ved at fremstille Ungarn som et offer for Tysklands aggression snare end som aktiv deltager, hvidvaskes de såkaldte etniske ungareres rolle i udryddelsen af de ungarske jøder. Der produceres eller opretholdes en adskillelse mellem jøder og rigtige etniske ungarer, således at det er svært ikke at få det indtryk, at jøderne ikke er ungarere, lyder bekymringen.

\section{"The Museum of Genocide Victims"}

På museet i Vilnius er det ikke ordet terror men aforismen folkedrab, der symbolsk forbinder nazismen og kommunismen og giver navn til museet. Ifølge museets leder Eugenijus Peikštenis er det museets formål er at indsamle, bevare og udstille historisk dokumentation af det fysiske og spirituelle folkemord på det litauiske folk samt omfanget af og de forskellige former for modstand mod Sovjetregimet. The Museum of Genocide Victims i Vilnius bygger således på den grundantagelse, at kommunismens undertrykkelse af den litauiske befolkning kan sidestilles med holocaust. ${ }^{13}$ Som i Budapest udstilles kollaboratører, for- rædere og gerningsmænd med billeder, data og navn.

I Litauen som i de øvrige baltiske lande er der, hvis mans er bort fra de russiske mindretalsgrupper, stort set konsensus om, at kommunismen kom udefra og ødelagde den kultur og det folk, der var der i forvejen. Denne fortolkning og erindring af den historiske periode, hvor Litauen var en sovjetrepublik, er det blevet et vigtigt nationalt projekt at formidle, fordi den opfattes som en sandhed, der bevidst blev fortiet under sovjetstyret, hvor det var den røde hærs befrielse af de baltiske lande, der blev erindret. ${ }^{14}$ Derfor blev museet også påbudt ved lov allerede i 1992 som et led i reetableringen af en national bevidsthed og det har aldrig været diskussioner om, hvilket perspektiv, der skulle anlægges. Omdiskuteret har derimod været et andet privat museum i Litauen, Grutas Park, som udstiller den sovjetiske materielle erindringskultur i en park, som er en mellemting mellem et frilandsmuseum og et Disneyland (se Otto 2009).

Museet i Vilnius skal formidle og optænde en nationalfølelse. En særlig genstand appellerer stærkt til nationalfølelsen. Det er en figur af den mytologiske nationalhelt Vytis, men det er ikke en hvilken som helst figur, der blot skal illudere den nationale ånd. Fordi denne efterladte og halvt ødelagte figur i huset blev brugt af de russiske soldater til at skyde til måls efter, er den mere end et symbol, den er en materialisering af forsøget på udslettelse af nationen. Den konkretiserer så at sige folkedrabet, og dens usle tilstand taler direkte til de nationale følelser, ikke mindst når der er engagerede omvisere $\mathrm{i}$ form af tidligere deporterede og modstandsfolk tilstede. Det er der altid ved besøg af skoleklasser, men de fungerer på grund af sprogbarrierer sjældent som formid- 
16 lere for det efterhånden anseelige antal turister, der besøger stedet.

Fangekælderen, som står næsten uberørt, betragtes som den vigtigste del af museet. Den blev indrettet som fængsel i 1940 efter Sovjets besættelse af Litauen. Som del af museet står den urørt, som den så ud da KGB forlod bygningen i 1991, bortset fra et par enkelte celler, hvor der er udstillinger. I én celle udstilles sække med makulerede papirer, som KGB nåede at fjerne fra arkiver og destruere. I en anden celle er der billeder af alle ledere og ansatte i KGB og i en tredje er der en udstilling For God and the Motherland, om regimets forfølgelse af kirken.

Klimaks i kælderudstillingen er The Execution Chamber, hvor der er foretaget en arkæologisk udgravning. I hullerne i den bare jord ligger genstande, som er gravet frem, et kors, en vielsesring, en stump pigtråd og knapper. Der er også udstillet en bunke sko og nogle briller. Det fremgår ikke, om de også er gravet op eller placeret her efterfølgende. Valget af netop disse genstande kan meget vel være en bevidst eller ubevidst henvisning til den famøse udstilling i Auschwitz museet, hvor der bag glas er udstillet bunker af sko, hår og briller, berøvet fra jøderne før de kom i gaskammeret. Sko og briller er intime ejendele, der har været i tæt berøring med folks kroppe, mens de endnu levede, og derfor er de virkningsfulde som kontaktpunkter for publikum, hvor den traumatiske historie gøres nærværende, men brugen af de samme genstande i holocaustudstillinger rundt omkring i verden bliver samtidig en slags dominerende kulturelt narrativ, som gør den oprindelige historiske begivenhed til en symbolsk repræsentation af menneskelig og politisk ondskab. Som genstande og udstillingssprog fungerer de som et materielt erindringskompleks i en global historiekultur. I
Vilnius fortæller de udstillingssproglige henvisninger til holocausterindringen, på det mere ubevidste plan, at der også er begået folkemord i Litauen på linje med (om end ikke i samme omfang) som Holocaust.

I stueetagen handler udstillingen om besættelsen og sovjetiseringen og modstandsbevægelsen. Ikke overraskende er det ikke-angrebspagten mellem Sovjet og Tyskland, den såkaldte Rippentrop traktat, der er fortællingens røde tråd. Den bærende fortælling er, at det blev Litauens skæbne at blive en socialistisk sovjetrepublik, fordi nationen blev forrådt af begge stormagter, som det ses på et foto af Stalin og Rippentrop, der smilende skåler for Hitler. Udstillingen om sovjetiseringen er holdt i rødt, som også på de andre museer bruges til at visualisere den kommunistiske socialisering. Derudover er der bøger, pengesedler, valgplakater og i det hele taget propaganda udgivet af Agitprop, som var en institution for visuel agitation og propaganda. Forfølgelsen af antikommunisterne er veldokumenteret med billeder og skriftstykker, men stærkest står en håndtegning af Stalin, hvor øjnene er skåret væk, så den kan holdes op som maske foran hovedet. Den var bevis i en retssag mod otte personer, der blev dømt for antikommunistisk virksomhed.

Den ni år lange modstandskamp og ikke mindst den organiserede modstandsbevægelses dagligdag er i centrum. Det er især de mange personlige genstande, der gør udstillingen nærværende. Der er udstillet små tegninger, autentiske fotos, håndskrevne sedler og genstande som smykker, religiøse billeder og bøger som giver publikum indblik i partisanernes ensomme liv i de store skove. Der er også små ting, som partisanerne har udskåret i træ. Ikke mindst er der utallige fotografier af partisanerne eller frihedskæmperne. 


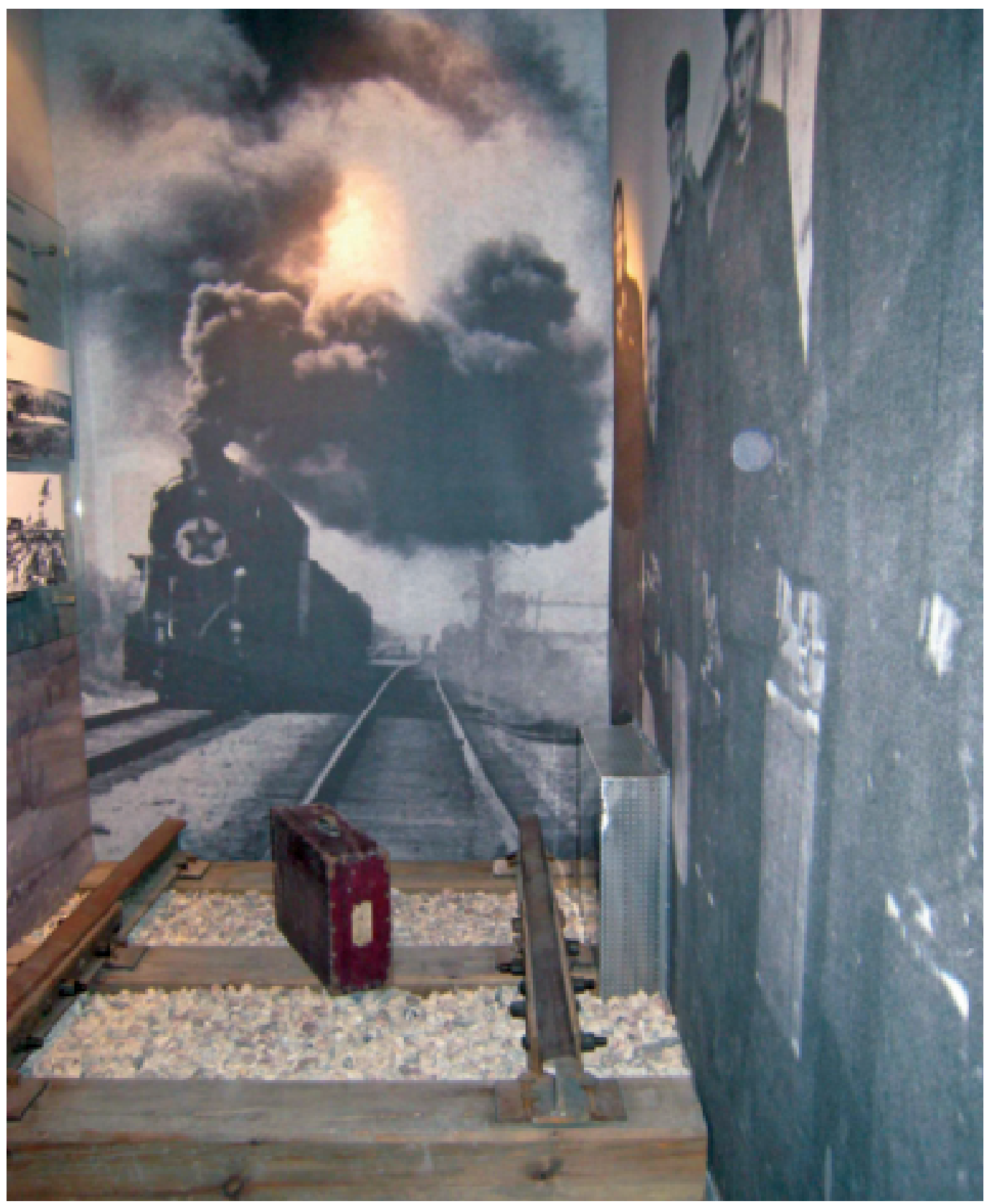

"Holocaust-udstillingssprog", Genocide Museum. Vilnius 2006. Foto: Lene Otto. 


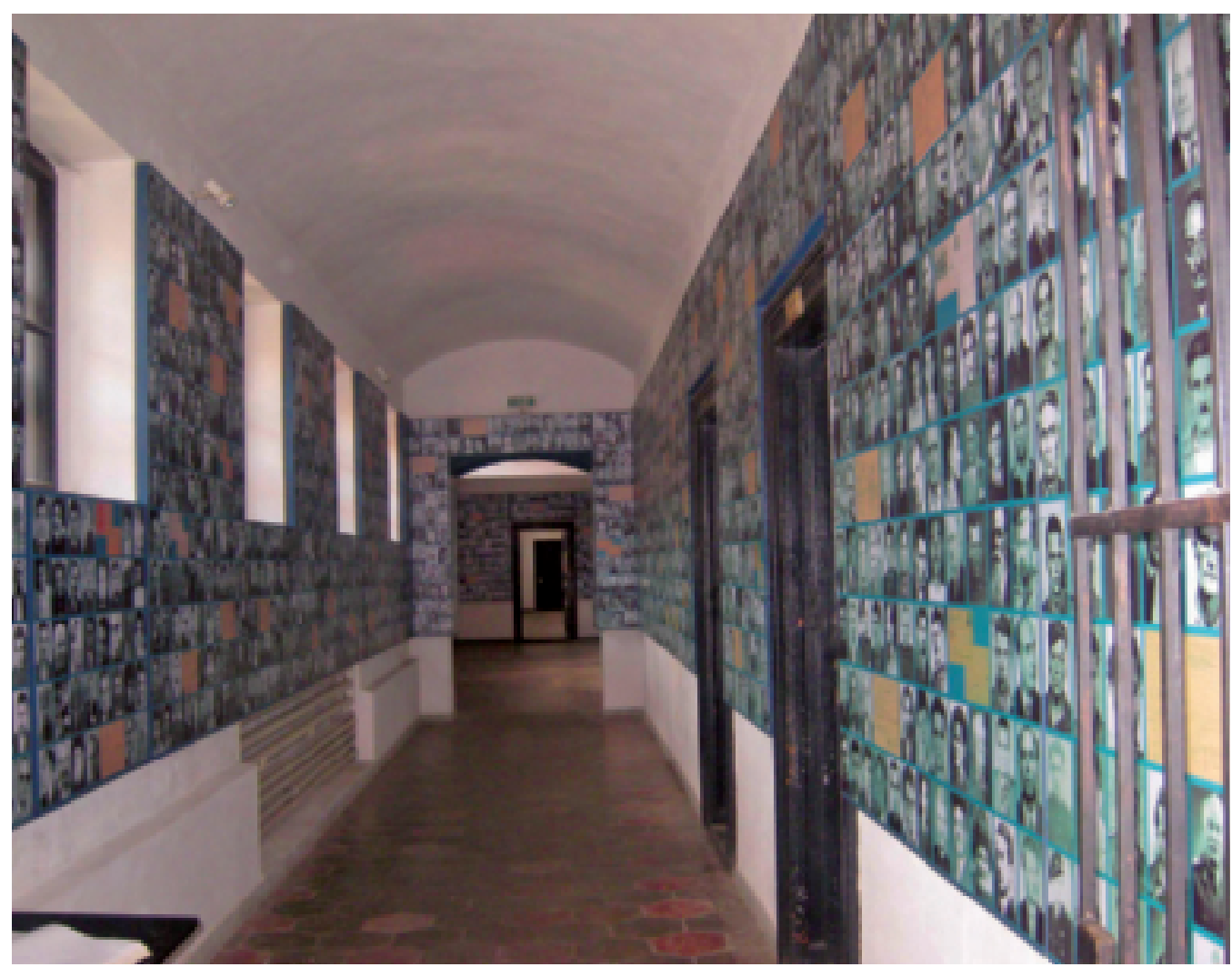

Fotos af kommunismens ofre, Sighet museet, Rumanien 2007. Foto: Lene Otto.

De deporteredes trængsler fylder naturligvis også meget i udstillingen. Arbejdslejrene skildres udførligt, men igen er det de deporteredes tøj, sko, bønnebøger, broderede klude, tegninger og breve, der skaber nærværet til fortiden. Der er noget særligt over de genstande, som hænder har rørt ved: broderier, tegninger og bøger, der er slidte af hænder, der har krammet dem samt små miniaturer, der er snittet eller formet af arbejdsomme hænder. Jo mere slidte og mærkede af brug de er, jo mere aura har de og jo mere opmærksomhed synes de at tiltrække. Disse ting har en metonymisk relation til den fortid, de fortæller om. De er fragmenter, ikke bare af fortiden, men også af de mennesker der fremstillede, formede, håndterede og holdt om tingene.

De deporteredes hjemkomst i slutningen af 50 'erne vises i form af et stykke togskinne, en kuffert og i baggrunden en fotostat af et tog. Igen ser vi det globaliserede materielle erindringssprog i brug, hvor togvognen og pigtråden, ligesom skoene og brillerne, har rødder i holocausterindringen, og som nu er blevet en del af det internationale udstillingssprog.

Den ikke-bevæbnede, såkaldte passive mod- 
stand, som graffiti, sedler med slogans, fejring af nationale helligdage, deltagelse i halv-religiøse processioner og besiddelse af nationale eller religiøse symboler, behandles også i udstillingen. Gennem 80'erne kommer modstanden til udtryk i forskellige bevægelser ledet af religiøse skikkelser, dissidenter og nationalister. Det er mest billeder og plakater og bannere og den slags. Til slut er der en opgørelse over de menneskelige tab under de to besættelser. Det drejer sig om ca. 30.000 personer under den sovjetiske besættelse og 330.000 under den tyske besættelse, men som i Buda- pest er det samlede indtryk at det var det var kommunismen som ideologi og styreform, der forrettede mest skade.

\section{"The Memorial SigheT"}

Fængslet ligger midt i byen Sighet (eller Sighetul Marmatiei). Det er en stor gul bygning, der stadig ligner et fængsel, og som både er museum og mindesmærke over de fanger der opholdt sig og døde i løbet af de 9 år fra 1944 til 1955 hvor fængslet fungerede som et 'rumænsk Gulag'. I gården står en statue-gruppe

Skulpturgruppen udenfor det forhenvarende fangsel, Sighet museet, Rumanien 2007. Foto: Lene Otto.

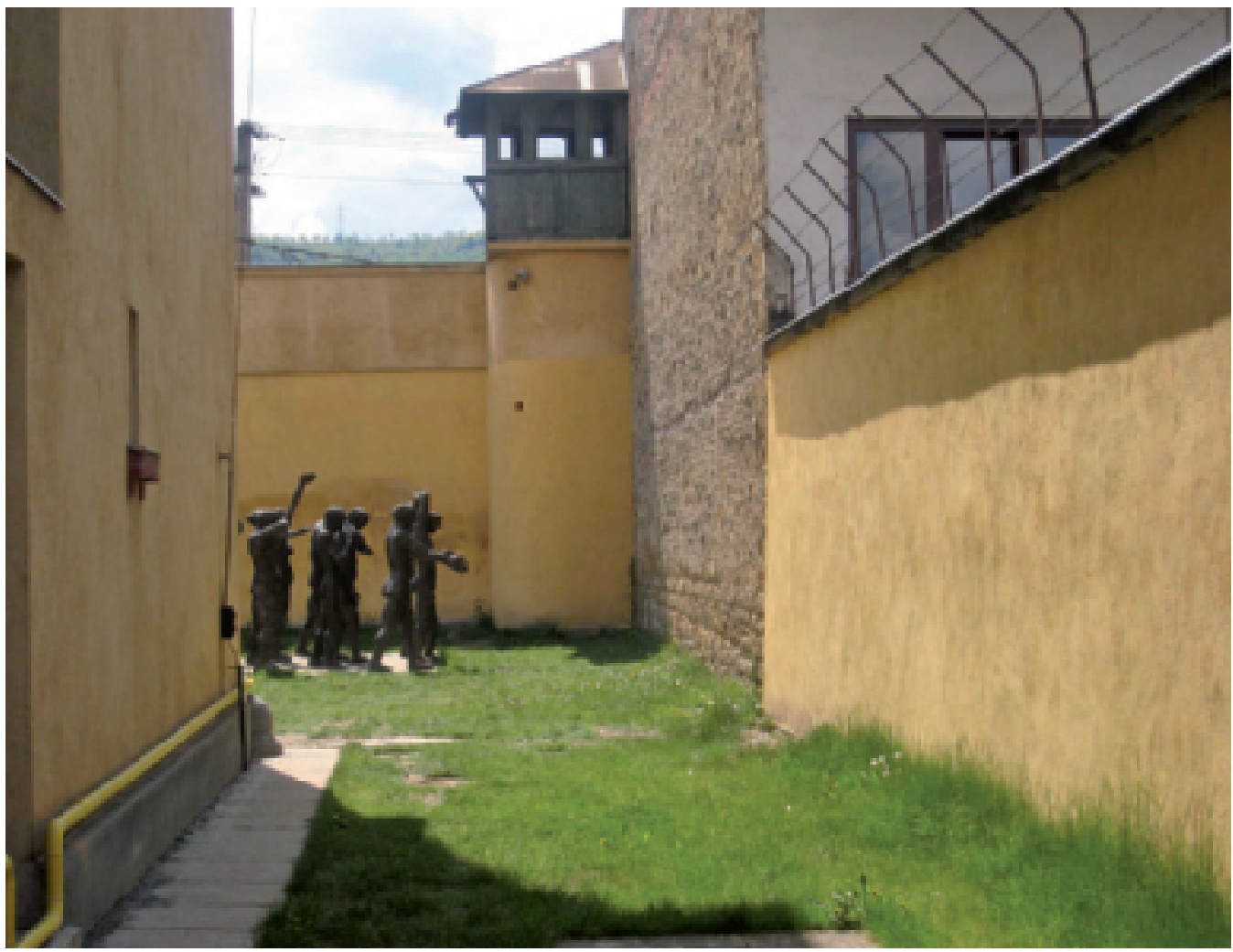


kaldet The convoy of martyrs, som er dette mindesmærkes særlige kendetegn. Det består af 18 personer, som går hen mod en mur, der spærrer for deres udsyn, sådan som kommunismen "had limited the lives of millions of people”. I gården kan man besøge en Hall of Remembrance and Prayer i gården, som er et underjordisk kapel eller erindringssted, hvor man kan tænde lys, bede og "pay your respect to their memory". På væggen langs den lange sneglegang derned er indgraveret tusindvis af navne på ofre.

I en særlig fløj er et studiecenter placeret, som indtil videre har produceret 3000 timers lydbånd med erindringer, 15.000 sider bogudgivelser og indsamlet titusindvis af dokumenter, fotos og lydbånd. I 2000 er der tilføjet endnu et modul som indeholder en moderne konferencesal, og hvor der hvert år holdes sommerskole. Museet lægger nemlig hus til en årlig summerschool for unge, som er ledet af den franske historiker Stéphane Courtois ${ }^{15}$ og finansieret af blandt andre Konrad Ardenauer fonden samt til efteruddannelse af lærere, så de kan blive kvalificeret til at undervise de yngre årgange i kommunismens undertrykkelse og den anti-kommunistiske modtand ${ }^{16}$ og til konferencer og møder om samme tema. Endelig organiserer museet også den årlige "Day of Remembrance" den 17. maj.

Uden for bygningskomplekset blev der i 1999 etableret en "kirkegård uden kors". Ifølge beretningen blev 52 politiske fanger, som var blevet dræbt i fængslet, begravet i al hemmelighed en nat, men ligene har ikke kunne identificeres blandt mange andre lig. Kirkegården er anlagt som et landskabsprojekt på i alt $14.000 \mathrm{~m}^{2}$. Rundt om en tom plads, som har form som Rumænien, er plantet træer, som med tiden vil forme et vegetabilsk amfiteater. Tanker er, at på denne måde vil landet

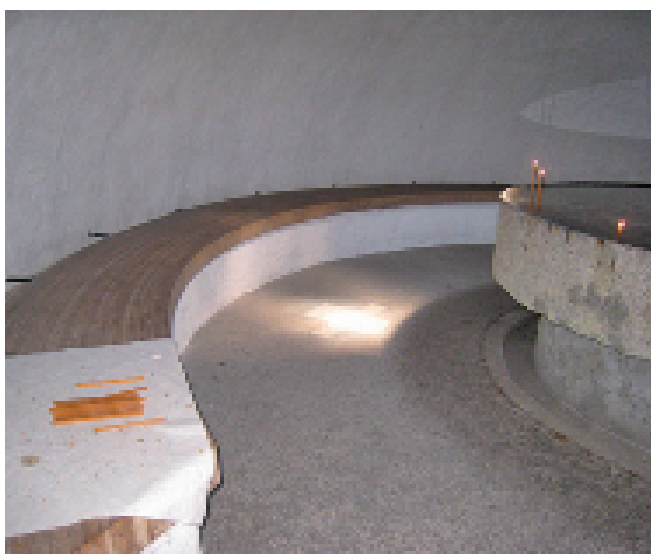

Erindrings- og sørgested hvor man kan tonde vokslys på Sighet museet, Rumanien 2007. Foto: Lene Otto.

"holde sine martyrer i armene og sørge over dem mens nye generationer af vegetation gror op”. Fra et nært liggende udsigtspunkt på bredden af Tiza, som udgør grænsen til Ukraine, vil besøgende kunne overskue kirkegåden - "this symbolic drawing more and more distinctly as nature perfects the project" (www. memorialsighet.ro).

Museets formål er uddannelse af borgerne ved at bibringe dem viden om landets fortid. Hertil kræves, ifølge aktivisternes opfattelse, en restaurering af Rumæniens fortid som blev fortiet eller forfalsket under kommunismen. Initiativtageren, digteren Ana Blandiana, som var en kendt kritiker under kommunismen, fik sammen med sin mand mobiliseret en interesse for projektet, som blev overdraget til Europarådet i 1993. To delegationer af eksperter besøgte Sighet og i en rapport fra 1995 gav rådet sin fulde støtte til museumsplanerne. I 1998 blev det kaldt for et af de vigtigste mindesmærker på det europæiske kontinent på linje med Auschwitz museet og Mindesmærket for fred i Caen i Normandiet. Museet skal 
"rebuild the memory of certain nations, particularly the Romanians, who for half a century have been misled with a false history" (The Exhibition Guide of the Sighet Museum).

Selve udstillingen består af en introduktion og 50 temaer udstillet i de tidligere fængselsceller. For at komme hen til cellerne med udstillingerne går man igennem en lang gang med væggene helt besat med portrætter på personer, der har siddet i fængslet, må man formode. Dette foto galleri som jo også blev brugt som virkemiddel på Terror House i Budapest, vurderes også i en anmeldelse på den rumænske nyhedsportal, som værende en særlig virksom form for historieformidling:

Because words can be forgotten, you bury the somewhere in the back drawer of the memory, but the faces of those who suffered imprint themselves forever. The corridor of portraits of the victims of communism is impressive. You can't pass through that place indifferently. (Boga 2007).

Udstillingen fortæller ikke en sammenhængende historie, men bygningen og bruges af cellerne lægger op til, at der er mange historier. Flere rum indeholder udstillinger lavet af og om særlige grupper, fx de deporterede. Kun to celler, hvor berømte rumænske intellektuelle anti-kommunister døde, står uberørte med jernseng og fængselsdragt samt to afstraffelsesceller kun med den jernring fangerne havde om benet, når de som straf måtte stå op, nøgne og barfodede i mørke. Derudover er der meget få originale genstande men mange kopierede billeder og dokumenter. I introduktionsrummet er der to store kort på væggene. Temaet er det rumænske Gulag. På kortet er markeret alle fængsler, arbejdslejre, samfund af deporterede, forhørssteder, Securitates lokale kontorer og psykiatriske institutioner af po- litisk karakter. Kortet virker knugende og det forstærkes af bunker af pigtråd, der vrider sig rundt på gulvet. Brugen er pigtråd er også en holocaustreference, en del af den globale holocaustikonografi, der fortæller om udryddelse mennesker, om folkemord.

Det første tema handler om hvordan kommunisterne blev valgt til magten i 1946 ved hjælp af svindel. Grundfortællingen er, at det kommunistiske Rumænien fra begyndelsen var et falsum, og resten af udstillingen skal dokumentere dette. Rumænerne er blevet indoktrineret og manipuleret med det resultat, at "the traces of this violation of national consciousness persist even today in the mentality of many members of the public" (The Exhibition Guide:12) Et enkelt sted bruges eufemismen et kulturelt folkemord om udrensningen af bøger og den begrænsede ytringsfrihed.

Både historierne om arbejdslejrene og tvangskollektiviseringerne er fortalt i et nøgternt og beskrivende sprog. Dokumentationen, i form af fotos taler for sig selv. Som der står i den engelske udgave af udstillingskataloget: "The numerous photos with biographical data of the prisoners give this room a solemn and tragic appearance." (The Exhibition Guide:15). Når der overhovedet indgår tredimensionelle genstande i udstillingen er det i form af konstruerede symboler snarere end som relikter, som der var så mange af $\mathrm{i}$ Vilnius. I rummet om tvangskollektivisering er der fx midt i rummet et fladt plateau, hvorpå der vokser græs "which stands for both the land, alive and free and the grave of those who sacrified themsleves for it." I et andet rum er der et stykke ikke originalt mur, der symboliserer Ceausescus ødelæggelse af Bukarest i hans forsøg på at gøre byen moderne. I samme rum er der lavet en model af et forhørslokale, hvor man kan kigge ind af et kighul på et skrive- 
22 bord med skrivemaskine og en lampe der med sit blændende lys er vendt mod den der forhøres. Tilsyneladende er der en udbredt enighed om, at forhørslokaler, ligesom pigtråd kan fungere som og vil blive forstået som metaforer for den undertrykkende kommunistiske stat, for et sådant lokale findes på de fleste museer om kommunismen. For udstillingssproget er temmelig neutralt og næsten uden metaforer og symboler til at aktivere følelserne. Tal, navne og begivenheder dokumenteres i teksterne, men de fortolkes ikke eller indgår ikke i en metafortælling.

Der er dog enkelte undtagelser. Det ene er et rum om kvinderne i fængslet. Her er der også både brugt stemmer, film, ansigter, livshistorier og mange genstande, som udtrykker kvindernes sorg over de børn, de er blevet adskilt fra. Den anden undtagelse er et rum om fængselspoesi. Digte blev morset gennem cellerne og senere nedskrevet efter hukommelsen. Her er der en direkte henvendelse til publikum:

We hope that this room will be understood as a profound homage to the poets who suffered, those who became poets through their suffering and to the people, capable of producing this amazing plant capable of growing in darkness: poetry in prison.

I modsætning til de andre museer er lidelserne ellers ikke i højsædet. Det sidste eksempel er et rum om det åndelige liv i fængslet, hvor der er udstillet ordbøger, spil, kors og en bog, som var "made by detainees with their own hands using improvised tools, hidden during searches." (The Exhibition Guide:19)

Endnu en ting, der adskiller museet i Sighet fra de to foregående er, at det forsøger at fortælle om kommunismen generelt og ikke kun om Rumænien som offer. Et helt udstillingsaf- snit er viet til de syv andre satellitstater i den såkaldte socialist camp (Albanien, Bulgarien, Tjekkoslovakiet, Østtyskland, Jugoslavien, Polen og Ungarn) og "as more documentary material is received from each country, new exhibitions dedicated to each will be completed" (The Exhibition Guide:14). Et andet afsnit handler om den polske Solidarnosc bevægelse ligesom der er temaer om foråret i Prag og den såkaldte fløjlsrevolution. Det viser at erindring og historisk analyse godt kan gå hånd $\mathrm{i}$ hånd på et museum.

\section{THE DDR MUSEUM}

En hel anden og tilsyneladende a-politisk måde at forholde sig til fortiden på, repræsenteres af DRR museet i Berlin. ${ }^{17}$ Det lille private museum ligger ved Spree lige over for det snart nedrevne Palast der Republik, symbolet på det socialistiske DDR's kulturpolitik. Museet, der i 2008 er nomineret til European $M u$ seum of the Year, er grundlagt af den tyske etnolog Peter Kenzelman, som ikke selv er vokset op i DDR. Det er etableret som et kulturhistorisk supplement til statshistorien, forstået på den måde at museet skal vise, at DDR var andet og mere end en sovjetisk satellitstat, der eksisterede på Moskvas nåde. DDR var mennesker, ikke kun ideologi eller terror. Genstandene er ikke hentet fra Tysklands "archives, but from it attics" (Spigel 2006). Tanken bag museet er, at man kun kan forstå et politisk system, når man forstår, hvordan hverdagslivet var for befolkningen. Fokus er derfor på mennesker og hverdagsliv snarere end på statens forbrydelser, terror og overvågning, selvom et lille hjørne af udstillingen omhandler statens sikkerhed, iscenesat med et skrivebord, hvorpå er placeret datidens enkle, men effektive overvågningsteknologi, høretelefoner og forstær- 


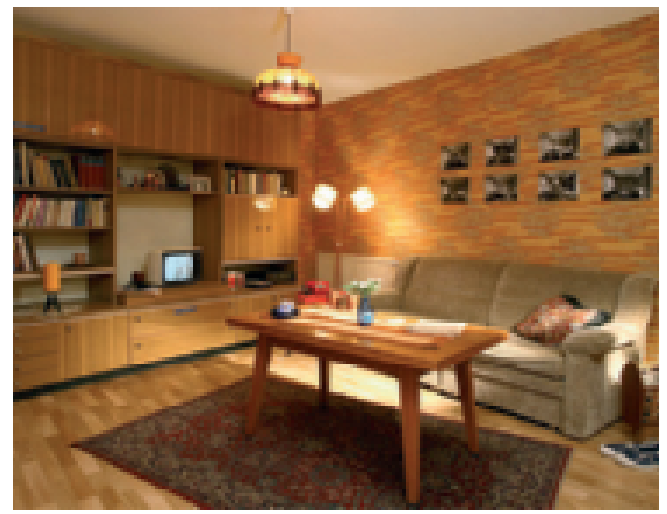

Interiør fra DDR museet. Publikum må sidde i møblerne, lase $i$ bogerne og kigge i skabene. Foto: Lene Otto.

ker og et par mapper, over skrivebordet et fotografi af Eric Honnecker.

Ellers går man forgæves, hvis man vil vide mere om den kommunistiske stat. Dog kan man finde en enkelt kronologisk oversigt over The rise and decline of a state, hvor vigtige begivenheder er beskrevet kronologisk. Tonen er tilstræbt neutral, men med et stærkt ironisk islæt, fx når begivenheder som Østtysklands deltagelse i nedkæmpelsen af oprøret i Prag i 1968 og Honneckers tiltrædelse i 1971 optegnes på linje med afholdelsen af den 10. ungdoms- og studenterfestival i Berlin i 1973 og sejren i en fodboldturnering i 1974.

Denne, i forhold til de foregående museer, ironiske og, efter nogens opfattelse, restituerende vinkel på kommunismen, er temmelig omdiskuteret i et Tyskland, hvor det 20. århundredes historie håndteres meget varsomt. Ethvert udsagn om nazismen vejes på en vægtskål og er det ikke balanceret, udløser det straks kritik. Det ville være utænkeligt at lave en udstilling om dagliglivet under nazismen, lyder et argument mod DDR museet (Winkler 2006). Den underliggende antagelse er, at nazisme og kommunisme skal behandles ens, fordi de er ens. DDR-museet anklages da også fra flere sider for at lukke øjnene for rædslerne, for i bedste fald at producere et billede af staten som bizar og for at ride med på en farlig "ostalgibølge" ${ }^{18}$ Direktøren for Stasi-mindesmærket Hohenschönhausen, Hubertus Knabe har således udtalt, at han er skeptisk overfor om "depictions of everyday life can explain life in a dictatorship" (Winkler 2006). De kritiske røster er enige om, at udstillingen mangler kontekst. Museets grundlægger og dets medarbejdere fastholder dog, at kommunismens kultur og dagliglivshistorie er lige så vigtig som kommunismens politiske historie. Østtyskland var en diktaturstat, men den var befolket af mennesker med glæder, kærlighed og drømme.

The GDR was more than just an artificial product of ideology and power - for millions of people it was their life. (Rückel 2006:11).

Museet skelner altså, i modsætning til andre museer om kommunismen, konsekvent mellem stat og befolkning og det er udelukkende sidstnævntes perspektiv, der er repræsenteret; den almindelige befolkning, som hverken var modstandere af eller ofre for regimet eller var politisk aktive i det hele taget. Der er ingen tvivl om, at museet på den måde både opfylder et behov hos Berlins mange besøgende, der gerne vil vide mere om, hvordan det var at leve i et kommunistisk land og et ønske hos de forhenværende DDR-borgere om at få anerkendt deres fortid som et værdigt liv, sådan som det fx udtrykkes af et par pensionister blandt det lokale publikum: "We've been put down as Neandertalers and this shows that we lived like normal people" (Winkler 2006).

I 2007 var der en anden udstilling om DDR 
24 på det nærliggende Deutsche Historische $\mathrm{Mu}$ seum. Udstillingen "Dictatorship and Everyday Life in the GDR" havde som formål at vise, hvordan de østtyske borgere indrettede deres dagligliv. Den var også tematisk opbygget, men indeholdt næsten kun genstande, der symboliserede borgernes relation til staten, så som dokumenter, partimedlemskort, uniformer, præmier, plakater, aviser. Man kan sige, at det der var den ideologiske konstruktion af hverdagslivet snarere end det oplevede hverdagsliv, der var i fokus. Den var mere analytisk og nøgtern, men helt uden indlevelse og anerkendelse. Emotionel indlevelse er derimod i højsædet på DDR-museet, hvor den stoflighed og sanselighed, der omgærder fortidens relikter, bruges meget bevidst:

Even symbols of the SED regime still tend to stir up oddly pleasant feelings in some of us. (Rückel 2006:11).

Derfor kan det ikke undre, at museets kritikere sætter museet i bås, og kalder udstillingen for nostalgisk. Det er jo ikke helt forkert, at museet rider med på den bølge af ostalgi, der i de senere år har resulteret i både film, bøger og en relancering af konsumprodukter, som blev produceret i DDR. I denne bølge spiller den materielle kultur en vigtig rolle som medspillere i fastholdelsen af østtysk identitet. Varer fra DDR-tiden er blevet symbolske markører for befolkningens særlige erfaringer under kommunismen, men de er ikke blot symboler, folk vil gerne have fysisk omgang med dem, som de kan på museet eller hvis de bestiller varer hjem via Internettet. Især produkter, der før var kilde til underlegenhed og flovhed, bliver rehabiliteret og brugt med stolthed og selvfølelse. Omgangen med og konsumtionen af disse produkter kan give følelsesmæssigt velvære, som museumsdirektøren er inde på i ovenstående citat og tingene kan netop også medvirke til at rekonstruere fornemmelsen af kontinuitet $\mathrm{i}$ livet.

Hele udstillingen på DDR-museet er i ét plan og man bevæger sig gennem alle de klassiske kulturhistoriske temaer, som vil være at finde på ethvert by - og kulturhistorisk museum: grænser, transport, ungdom, uddannelse, arbejde, konsumtion, bolig, familie, medier, mode, kultur, ferie - og som det særlige for Østtyskland - statssikkerhed. Den gennemgående udstillingsarkitektoniske tråd er de berygtede boligblokke, elementbyggeri i beton, hvis monotone facader, i mindre målestok, fungerer som vægge og montrer i udstillingen. Nogle af vinduerne er små montrer, andre steder er der skærme og de nederste "etager" fungerer som skuffer, der kan trækkes ud. Designet i sig selv understreger udstillingens pointe, at på trods af den udbredte opfattelse af Østtyskland som grå og ensformig, var der masser af kulør, livsglæde og humor bag facaderne.

Som i Budapest åbnes udstillingen med et

Udstillingsmontrerne bygget med reference til de endelose betonboligblokke i de østtyske byer. Foto fra DDR museet, Berlin 2007. Foto: Lene Otto.

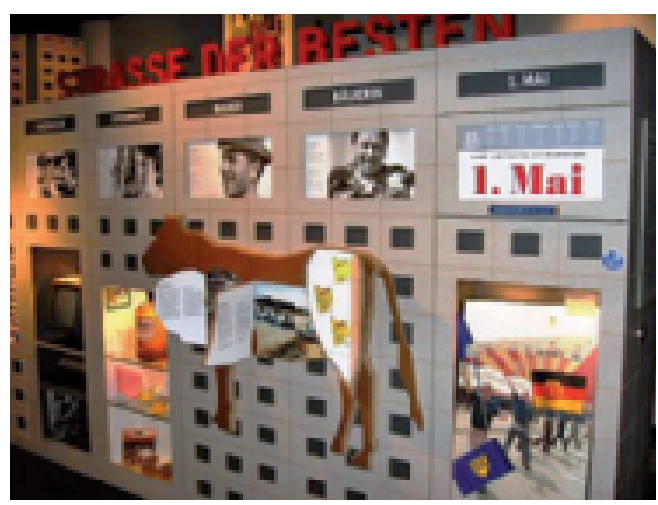


ikon, her er det dog ikke en monstrøs, sovjetisk tank, men en lille beskeden Trabant, som publikum kan prøve at sidde i. Interaktiviteten er central i udstillingen, idet hvert tema er bygget op omkring materielle genstande, som publikum kan undersøge med deres egen hænder. Det at man må åbne, tage op, bladre, undersøge, snuse til og føle på genstandene, er nok udstillingens største attraktion. Når publikum kan sidde i en trabi, trække skuffer ud med ting fra ungdomspionererne, tage skolebøger op af skoletasken og kigge på regnehefter og skrivebøger samt sidde i sofaen $i$ en af de masseproducerede betonlejligheder og se fjernsyn, tage en bog fra reolen eller gå ud i køkkenet og tage varer og husgeråd ud af køkkenskabene, får de en anden forståelse af fortiden. De kendte ting transformeres fra symboler på et disciplineret og undertrykt mangelsamfund til livshistoriske genstande. Tingene gør det muligt at indleve sig i og berøres af menneskers livshistorier snarere end de giver en forståelse af kommunismen som ideologi og system. Har man levet i 50'erne, 60'erne eller 70'erne, uanset om det var i øst eller vest, er der meget, der er genkendeligt og tingene kan ikke undgå at vække lidt nostalgi. Publikum må få den opfattelse, at man på begge sider af muren levede på næsten samme måde, blot var der færre varer at vælge imellem i øst. Det er en helt bevidst strategi, for museet er en reaktion mod den diskurs, at livet i DDR var en lidelse, det er en kliché, som hører den kolde krig til og som museet ser det som sin opgave at nuancere, mener lederen Robert Rückel, som forsvarer museets strategi mod de kritikere der siger, at museet dermed skjuler, at DDR var et diktatur, ved at spørge:

... why does having a broader look at a topic automatically count as palliating the facts? Is it not in fact the ot- her way around? Do not those who leave out certain aspects in their scientific research, and especially in their presentation, demonize the truth? (Rückel 2006:4).

\section{KOMMUNISMEN PÅ MUSEUM}

Den museale erindringspraksis er både en politisk praksis og en æstetisk praksis. Formsproget er i sig selv en del af tolkningen og skabelsen af erindringen. Derfor vil jeg til sidst sammenfatte nogle iagttagelser vedrørende udstillingssproget og hvordan det kan tænkes at virke identitetspolitisk.

Der er tydeligvis sket en afsmitning af det psykoanalytiske sprog på historieforståelsen, idet der lægges op til at behandle den psykologiske og kulturelle erindring analogt. Et udbredt eksempel er psykologiseringen af den kollektive erindring, som når der fx tales om at nationer kan have traumatiske erindringer eller at genfundne erindringer er nødvendige for at kunne leve videre. Således bliver musealiseringen af den kommunistiske periode led i en renselsesproces, hvor den objektive fremstilling skal forenes med en angerfuld men følelsesmæssig accept af historien. Flere af museerne er grundlagt på steder og $\mathrm{i}$ bygninger som et fængsel eller et politi-hovedkvarter med afhøringslokaler, hvortil der naturligvis er knyttet traumatiske erindringer. Det gælder således for de tre museer i Sighet, Budapest og Vilnius. Således er den emotionelle tilgang er så at sige forprogrammeret, når publikum træder ind $\mathrm{i}$ bygningen.

I de her omtalte museer om kommunismen er der en overordnet fortælling, der styrer og som også kommer til udtryk i museernes navne: folkemord, besættelse, terror, modstandskamp, ofre, det eneste alternativ er tilsyneladende det ironisk-sentimentale museum. Det er ikke uvæsentligt, hvordan historien fortæl- 
26 les. Terror og folkemord indgår ofte i den brede globale erindringspolitiske diskurs om kommunismen, som også omfatter andre medier end museerne. Det udbredte argument er, at det er ukendt og uproblematiseret, at kommunismen i bred forstand og mere snævert stalinismen var ansvarlig for flere folkemord $i$ verden. Det berettiger til at bruge ordet holocaust om de kommunistiske staters behandling af deres befolkninger. Imod denne tolkning kæmper Jødiske organisationer, som ikke ønsker at udbrede betegnelsen til at omfatte andre folkemord ud fra en antagelse om enhver sammenligning er en relativering. ${ }^{19}$

Når fortiden tematiseres som folkemord eller terror lukker man samtidig af for muligheden for at kommunismen som system kan analyseres og forstås, fordi sådanne forsøg uundgåeligt vil blive opfattet som forsvar for folkedrab. Denne tolkningsstrategi støttes ikke mindst fra amerikansk side og er bestemt ikke udelukkende et østeuropæisk fænomen. ${ }^{20}$

\section{MATERIALISERING OG FORTOLKNING}

Tendensen til at sidestille kommunisme og nazisme retorisk og materielt, det vil sige udstillingsteknisk, behøver selvfølgelig ikke at betyde, at publikum automatisk godtager denne fortolkning. Der er dog ingen tvivl om, at museernes erindringspolitiske betydning er stor, blandt andet ved anvendelsen af holocaust-ikonografi, der er udviklet i den såkaldte holocaust-erindring. Holocaust som symbol på nazismen er blevet en del af det globaliserede menneskes erindring, og for de nævnte museer tilstræbes det direkte og indirekte, at Gulag får samme status. Genstande som leder publikums fortolkning $\mathrm{i}$ den retning er $\mathrm{fx}$ et stykke jernbaneskinne med en transportvogn. Fordi alle europæere erindrer holocaust på no- genlunde samme måde, takket være museer, film og tv-dokumentarer, vil kvægvognen som symbol på jødeudryddelsen, når den opstilles til at illustrere deportationen til Sibirien, kort og godt fortælle at Gulag også var et holocaust, et folkemord. Andre elementer fra holocaust-erindringen er pigtråd, som symboliserer diktatur og personlige ejendele, især sko. Som Feldman skriver: "children's shoes have become metonymic contact points within standardized set of global museum routines." (Feldman 2006:261). Og så er vi tilbage ved formsproget som både æstetisk og politisk praksis. Spørgsmålet er, om det materielle kun er redskaber for politiske ideer eller om det også deltager i konstitueringen af disse ideer.

Inden for nyere materialitetsforskning diskuteres det, hvordan det materielle og det mentale er forbundet. I museumsverdenen tages det for givet, at fortiden er lagret i det materielle og derfor har en kognitiv virkning. Der er dog langt fra en entydig teoretisk forståelse af, hvordan fortiden i museerne kan være tilstedeværende på en ontologisk måde, som rækker ud over dens repræsentationer. Ét bud på en forståelse er tesen om, at fortidens materielle rester skaber et nærvær, så den enkelte fornemmer fortiden (Runia 2006, Gumbrecht 2004). Materialiteten fortæller ikke, men er til stede som en fysisk del af fortiden i nutiden. Tingene er selv overlevede rester, som fordi de er fremmedlegemer i nutiden, ved deres tilstedeværelse skaber en ikke intenderet forbindelse. Det nærvær til fortiden som publikum således oplever, kan ikke på samme måde vækkes, når ting bevidst bruges som en repræsentation af en fortolkning, hvor de indgår som metaforer i en fortælling. Nærvær derimod, opstår spontant, når tingene i kraft af deres fysikalitet gør historien ontologisk tilstedeværende. Det er derfor at autentiske ting, der er 
fremstillet af eller har været i fysisk forbindelse med menneskers hænder og kroppe kan siges at præsenterer fortiden, snarere and at re-præsentere den.

Det er denne mulighed for interaktion med fortiden, som museer og historiske mindesmærker giver mulighed for og det er også heri deres tiltrækningskraft består, ifølge Runia, fordi mennesker ikke kun længes efter betydning, forstået som fortolkning, mening, kendsgerninger, men efter virkelighed, forstået som historiens håndgribelige tilstedeværelse. Vi er drevet af en virkelighedshunger, en passion du reel:

For it is, I think, not a need for meaning that manifests itself in, for example, nostalgia and retro-styles, in the penchant for commemorations, in the enthusiasm for remembrance, in the desire for monuments, in the fascination for memory. My thesis is that what is pursued in the Vietnam Veterans Memorial, in having a diamond made "from the carbon of your loved one as a memorial to their [sic] unique life", in the reading of names of the anniversary of the attack on the World Trade Centre, in the craze for reunions, and in the host of comparable phenomena, is not "meaning", but what for lack of a better word I will call "presence. (2006: 5).

Også Feldman argumenter for, at relationen mellem museumsgenstande og publikum ikke først og fremmest er visuel. I stedet beskrives museer som arenaer for social kontakt og museumsgenstande som en slags metonymiske kontaktpunkter:

Contact points in the museum can take many shapes, but they involve and are engaged not just through an analytical gaze, but through the full range of bodily senses. In the contemporary world where museums play an every increasing role in global politics, having a sense for contact, therefore, will increasingly constitute the basic act of ethnography and history. (Feldman 2006: 266).

\section{KOMMUNISMENS KULTURARV}

Museerne i de postsocialistiske lande har fået den utaknemmelige opgave at tage vare på den ubekvemme kulturarv, kommunismens materielle levn. Der er ofte tale om en slags fremmedlegemer, som ved deres blotte tilstedeværelse skaber en for de fleste mennesker uønsket forbindelse til fortiden. Denne opgave er ikke en uskyldig leg med udstillingssprog og virkemidler, det er et eksistentielt anliggende for borgerne i de respektive lande, og i sidste ende handler det om, hvilken rolle kommunismen skal spille i den europæiske erindring. Skal europæerne huske kommunismen som en historisk epoke, der defineres af nogle årstal og som indeholdt både godt og skidt, eller var den en tragisk og traumatiserende begivenhed, der ikke bare kan inkorporeres i den normale erindring, men må behandles "for sig selv", ligesom Holocaust? Kampen om fortiden handler som bekendt om nutiden og fremtiden. I den politiske kamp mellem højre og venstre i de post-socialistiske lande, kan museernes forvaltning af den kollektive erindring komme til at spille en meget direkte rolle.

Et spørgsmål, der melder sig, når man ser på de forskellige erindringsstrategier museerne lægger for dagen er, hvorfor håndteringen af kommunismens materielle kultur er så emotionelt ladet. Den er på én gang afskyvækkende og attraktiv. Statuer som var inderligt uønskede mens de befandt sig i gadebiledet bliver attraktive når de flyttes ind $\mathrm{i}$ en ny kontekst. De skifter status fra at have været objekter, der stod som metaforer for kommunismens magt 


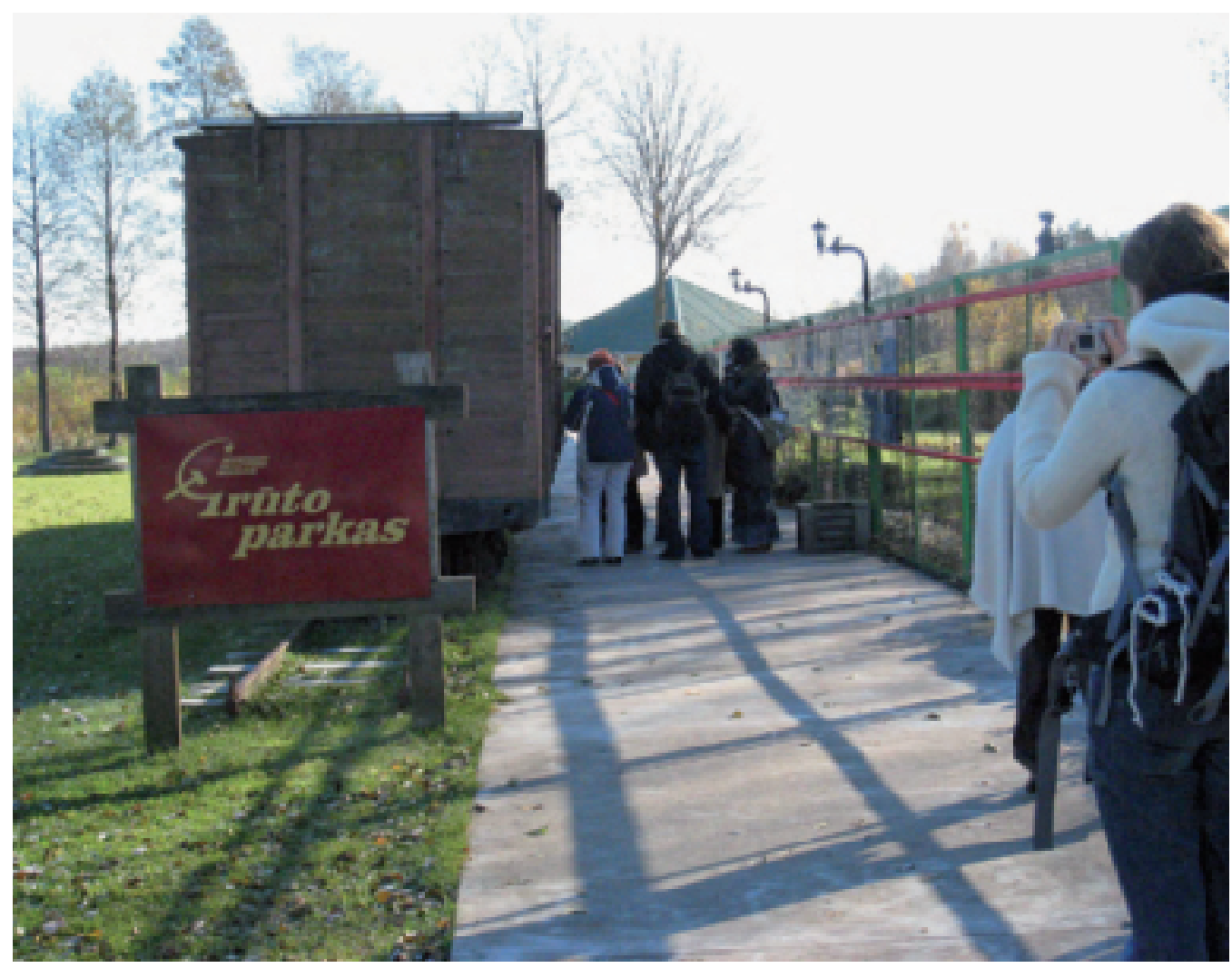

Grutas Park, ironisk benaunt "Stalin World". Litauen 2006. Foto: Lene Otto.

til at være objekter, der i kraft af den metonymiske relation til kommunismen kan indgå $\mathrm{i}$ en performativ erindringsproces, nærmest en renselsesproces. Kommunismen objektiveres og gøres til et fremmed land, man kan besøge. Det er også tankevækkende, at erindringsarbejdet på museerne om kommunismen betjener sig at af et religiøst konnoteret formsprog. Der er en gennemgående brug af religiøs symbolik i form af religiøst prægede installationer, hvor ikke mindst de sovjetiske satellitstaters martyrrolle personificeres af Jesus. Altre (i katolsk forstand) eller en fangedragt ophængt som på et kors er eksempler på dette, men flere museer tilbyder også en religiøs ritualisering af erindringen.

I det hele taget kunne de nye museer i det 'nye Europa' gøre til genstand for en langt mere dybtgående museologisk forskning, fordi de befinder sig i en etableringsfase, hvor de kulturhistoriske museumsudstillinger omfattes med eksistentielle følelser og tillægges stor politisk betydning, hvorfor brugen af historien og konstruktionen af kulturarv så at sige foregår for åbent tæppe. Jeg har her blot fremdraget nogle iøjnefaldende træk og nogle mu- 
lige (identitets)politiske implikationer af den måde kommunismens kulturarv forvaltes på. Jeg vil ikke forsvare den ene strategi frem for den anden, da der er brug for langt flere kritiske analyser af museerne i det erindringspolitiske felt. Det giver så anledning til overvejelser om, hvilken alen kvaliteten af de østeuropæiske museers forskning og formidling skal måles med. Skal de bedømmes efter en anden standard end andre europæiske museer og udstillinger, fordi de mere direkte er instrumenter i (re)konstruktionen af nye postsocialistiske nationale identiteter og fordi man i disse lande har haft kortere tid til det selvrefleksive erindringsarbejde eller er en sådan holdning tværtimod udtryk for en slags kolonialismen, fordi man hermed implicerer, at forventninger til "de andre" er beskedne? Den diskussion løb også som en rød tråd gennem oplæggene og diskussionerne på symposiet i Weimar, men et svar nåede de aldrig frem til.

\section{NOTER}

1. Det 3. internationale Symposium: "Der Kommunismus im Museum”, oktober 2004 i Weimar, arrangeret af Stiftung Ettersberg og Stifung zur Aufarbeitung der SED-Dikatatur.

2. Knigge, Volkhard \& Mählert, Ulrich (Hg.): Der Kommunismus im Museum. Formen der Auseinandersetzung in Deutschland und Ostmitteleuropa. Böhlau Verlag Köln Weimer Wien 2005.

3. Foruden en lang række mindesmærker og monumenter, virtuelle museer og utallige lokalmuseer, er der også flere andre museer i Østeuropa, som omhandler kommunismen, fx Checkpoint Charlie i Berlin, Museum of Occupations i Tallin, Museum of Communism i Warszawa, Museum of Communism i Prag, The Gulag Museum i
Perm i Rusland, Museum of the Occupation of

Latvia i Riga. Flere ad disse vil blive inddraget indirekte, da jeg har besøgt flere af dem i de senere år.

4. En betegnelse lanceret af Williams (2007) i bogen Memorial Museums. The global Rush to Commemorate Atrocities.

5. Dermed vil jeg ikke hævde at denne tendens kun findes i det tidligere Østeuropa. At oprette nye typer af kulturelle institutioner, der kombinerer museal formidling af viden med at være steder for sorgbearbejdelse og fremme af fred og tolerance i fremtiden, er måske en bredere tendens, der udover det globale boom i holocaustmuseer omfatter museer oprettet til erindring om specifikke begivenheder som folkedrab, apartheid, terrorisme og kolonialisme.

6. En af konklusionerne på Weimar symposiet var også, at "die Erzeugung von Emotionalität und Betroffenheit ein Hauptmittel zur Auseinandersetzung mit der kommunistischen Vergangenheit ist .." (Knigge \& Mählert 2005: 209).

7. "The objectives of the centre are to establish historical truth and justice; to investigate the physical and spiritual genocide of Lithuanians carried out by the occupying regimes between 1939 and 1990, and the resistance to the regimes; to immortalise the memory of the freedom fighters and the genocide victims; and to initiate the juridical evaluation of the aftermath of the occupying regimes. The centre also researches into the policy of the occupying regime in the Vilnius district from 1920 to 1939 and the processes of resistance to it." (http://www.genocid.lt/centras/en/)

8. Fra udstillingsteksten: "The Soviet occupiers set up a "new world order" in Hungary, in which there was no place for old values, old virtues. It was a Soviet world, fit for Soviet-type people, but alien and unacceptable to the majority of Hungarians." 
9. Fra udstillingsteksten: "The brave ones, who defied thee atrocious terror regime, were wiped out and buried in unmarked graves, because even in death they represented a threat. The oppressive system did everything in its power to eradicate even their memories. Those, who risked their lives for the freedom of the country, were branded spies and traitors. We do not know the names of many of them, and old lies keep circulating about some of them. Yet they were true heroes."

10. Fra udstillingsteksten: "In addition the organization, initially made up of ex-labour service men, far-left elements, criminals an a great number of former Arrow Cross henchmen, was given the task by the Communist Part to obstruct the development of constitutionalism, thereby preparing the ground for the Communist Party's takeover."

11. Fra udstillingsteksten: "The mind-set suggested by the crudely garish posters was just as mendacious and miserable as the ideology behind it."

12. http://www.terrorhaza.hu/index3.html

13. Ordet Holocaust (med og uden stort $\mathrm{H}$ ) blev først brugt efter 1967 og massivt først fra 1978, blandt andet på grund af en tv-serie med dette navn. Det store $\mathrm{H}$ bruges til at betegne den unikke katastrofe, der overgik jøderne, og kun dem. Finkelstein (2000) forklarer, at holocaust (med lille h) beskriver den faktuelle historiske begivenhed, mens Holocaust (med stort $\mathrm{H}$ ) snarere er begivenhedens ideologiske repræsentation. Holocaust er blevet inkluderet i den fælleseuropæiske bevidsthed som en slags grundfortælling.

14. Samme uenighed over fortolkningen af de historiske begivenheder i 1945 som enten befrielse eller besættelse sås i Estland så sent som i 2007, hvor et mindesmærke over den røde hær i form af en bronzesoldat blev fjernet fra en central plads i Tallinn efter vedtagelsen af 'The Law on Forbidden Structures', der som formål netop havde at lovliggøre en fjernelse af materielle min- desmærker fra sovjettiden, trods modstand fra det store russiske mindretal. Hændelsen førte da også til demonstrationer, konfrontation med politiet og et dødsfald og udløste endda påtale fra Europarådets kulturarvskontor.

15. Internationalt berømt kritiker af kommunismen og forfatter til bestselleren The Black Book of Communism: Crimes, Terror, Repression, udgivet i Harvard i 1997.

16. Dette arbejde er i overensstemmelse med anbefalinger fra Europarådet (no.1283/1996) og Ministerrådet (no. 15/2001) vedrørende undervisning $\mathrm{i}$ historie i det 21. århundrede, som understreger vigtigheden af at formidle viden om kommunisme og anti-kommunististisk modstand.

17. "A lively, interactive and entertaining approach to history: the GDR Museum examines life in the German Democratic Republic from every angle. As the first and only museum to deal with everyday culture in Berlin, it forms the third building block in the broader processing of GDR history." (http://www.ddr-museum.de/en/).

18. Ironisk nok roses museet i Europarådets præsentationer af kandidaterne til den europæiske museumspris for at gøre netop det modsatte: ”The presentation of all facets of normal life helps to counteract the nostalgic tide of 'Ostalgie" (Report: 27).

19. Ifølge den juridiske definition i FN-konventionen er folkedrab "en bestræbelse på systematisk at udrydde alle eller store dele af en gruppe mennesker alene ved henvisning til deres gruppetilhørsforhold", hvorved udryddelse af personer med henvisning til politisk tilhørsforhold eller overbevisning ikke er omfattet.

20. Amerikanske medier og konservative organisationer fremhæver gerne, at 100 millioner døde i kommunismens holocaust mod de kun 11 millioner ofre for nazismens holocaust. Højrekræfterne i USA, repræsenteret af Heritage Foundation mfl har længe arbejdet for, at også USA rej- 
ser en statue til minde om "victims of communism, tragically numbering more than 100 million, struck down in an unprecedented imperial communist holocaust through conquests, revolutions, civil wars, purges, wars by proxy, and other violent means." I 2007 afsløredes et mindesmærke "Victims of Communism Memorial" i Washington DC.

\section{REFERENCER:}

Agamben, Giorgio 1999: Remnants of Auschwitz. The Witness and the Archive New York: Zone Books.

Antze \& Lambek (eds) 1996: Tense Past. Cultural Essays in Trauma and Memory. Routledge, New York, London.

Boga, Bodan: Sighet Prison - we are made to forget. Press Review, www.ziare.com, 22.10.07.

Crane, Susan (ed) 2000: Museums and Memory. Stanford University Press, California.

Edwards, Grosden \& Phillips (eds.) 2006: Sensible Objects. Colonialism, Museums and Material Culture. Berg. Oxford, New York.

Feldman, Jeffery D. 2006: Contact Points: Museums and the Lost Body Problem. In: Edwards, Grosden \& Phillips (eds): Sensible Objects. Colonialism, Museums and Material Culture. Berg. Oxford, New York.

Finkelstein, Norman 2000: The Holocaust Industry. Verso Books.

Fogu, C, \& Kansteiner, W. 2006: The politics of memory and the Poetics of history. In: Lebow, Kansteiner \& Fogu (eds): The Politics of Memory in Postwar Europe. Duke University Press. Durham and London.

Gumbrecht, Hans Ulrich 2004: The Production of Presence: What Meaning Cannot Convey. Stanford University Press.

Knigge, Volkhard \& Mählert (Hg.) 2005: Der Kom- munismus im Museum. Formen der Ausinandersetzung in Deutschland und Ostmitteleuropa. Böhlau Verlag Köln Weimar Wien.

Lebow, Kansteiner \& Fogu (eds) 2006: The Politics of Memory in Postwar Europe. Duke University Press. Durham and London.

Light, Duncan 2000: Gazing on communism: heritage tourism and post-communist identities in Germany, Hungary and Romania. Tourism Geographies 2(2):157-176.

Maure, Marc 2006: Kulturminnene fra GULag-arkipelet mellom glemsel of erindring. Nordisk $\mathrm{Mu}$ seologi 2: 3-26.

Otto, Lene 2009: Kommunismen materielle kultur. In: Damsholt, Jespersen, Otto og Simonsen (red.): Materialitetens forfatning. (forthcoming)

Runia, Eelco 2006: Presence. History and Theory: 129.

Rückel, Robert (ed.) 2006: A guide to the permanent exhibition. A hands-on experience of everyday life. DDR Museum Verlag, Berlin.

Schmidt, Mária 2005: Our Common National Commemoration Pace - the House of Terror Museum. An interview with Mária Schmidt, Diplomata 20-10-2005.

Spigel Online: Museum Offers 'Ostalgic' Look at East Germany. 07/20/2006.

The Exhibitions Guide of The Sighet Museum. (upubl., u.å.)

Troebst, Stefan 2005: "Was für ein Teppich?" Postkommunistische Erinnerungskulturen in Ost(mittel)europa. Knigge \& Mählert (Hg.): Der Kommunismus im Museum. Formen der Ausinandersetzung in Deutschland und Ostmitteleuropa. Böhlau Verlag Köln Weimar Wien.

Williams, Paul 2007: Memorial Museums. The global Rush to Commemorate Atrocities. Berg, Oxford og New York.

Young, James 1993: The Texture of Memory: Holocaust Memorials and Meaning. New Haven, Conneticut. 
Lene OtTo

32

*Lene Otto

Associate professor, European Ethnology

Address: University of Copenhagen

Njalsgade 80, 2300 København S

Phone: +45 35329464

E-mail:lotto@hum.ku.dk 